\title{
MEMINIMALISIR ASIMETRI INFORMASI MELALUI PELAPORAN (DISCLOSURE) LAPORAN KEUANGAN
}

\author{
Ahmad Agung Prasetyo ${ }^{1^{*}}$ \\ ${ }^{1}$ Program Studi Akuntansi, Fakultas ekonomi, Universitas Tidar \\ E-mail: Ahmadagungpras18@gmail.com
}

\begin{abstract}
Abstrak
Penelitian ini bertujuan untuk memberikan gambaran tentang pentingnya penggunaan pengungkapan (disclosure) atas laporan keuangan dalam upaya untuk meminimalisasi asimetri informasi. Desain penelitian ini adalah studi kepustakaan dengan metode analisis yang digunakan berupa analisis deskriptif. Hasil penelitian menujukkan bahwa timbul asimetri akibat dari prinsipal di lain pihak sangat membutuhkan semua informasi yang relevan tentang kondisi perusahaan secara keseluruhan, tetapi tidak rnempunyai akses terhadap informasi internal perusahaan, tetapi informasi tersebut sangat berguna untuk pengambilan keputusan ekonomi. Berdasarkan fenomena tersebut timbul dari kurangnya transparansi dalam laporan keuangan agen menyebabkan penulis merumuskan masalah terkait dengan tujuan pendisclosuran, keuntungan dan kerugian serta hubungan antara pendisclosuran terhadap pendisclosuran terhadap asimetri.
\end{abstract}

Kata Kunci: Pengungkapan, pelaporan keuangan, asimetri informasi.

\section{Abstract}

This study aims to provide an overview of the importance of using disclosure on financial statements in an effort to minimize information asymmetry. The design of this research is a literature study with the analytical method used in the form of descriptive analysis. The results show that asymmetry arises as a result of the principal on the other hand in dire need of all relevant information about the condition of the company as a whole, but does not have access to the company's internal information, but the information is very useful for making economic decisions. Based on this phenomenon arising from the lack of transparency in the agent's financial statements, the authors formulate problems related to disclosure objectives, advantages and disadvantages and the relationship between disclosure and disclosure and asymmetry.

Keywords: Disclosure, financial reporting, information asymmetry.

\section{1) PENDAHULUAN}

Pada umumnya dalam menjalankan suatu usaha, pemilik menggunakan jasa orang lain untuk membantu mereka dalam menjalankan kegiatan usahanya. Namun, kemampuan untuk membuat keputusan strategis biasanya masih berada di tangan pemilik secara keseluruhan. Seiring dengan bertambahnya kompleksitas dan ukuran bisnis, pemilik tidak dapat lagi fokus menjalankan bisnis, sehingga mereka mendelegasikan sebagian kekuasaannya kepada orang lain, yang biasanya diposisikan sebagai manajer untuk menjalankan bisnis. Hal yang sama juga terjadi di korporasi. Sejak didirikan, sebuah korporasi telah memisahkan kekuasaan antara pemilik dan pengelola (manajer).

Hubungan keagenan didefinisikan sebagai hubungan di mana satu atau lebih individu yang disebut prinsipal akan mempekerjakan individu lain/organisasi lain, yang disebut agen 
untuk melakukan layanan tertentu, dan mendelegasikan wewenang pengambilan keputusan kepada agen (Brigham et al., 1999 dalam Handoko, 2002). Asumsi dalam teori keagenan adalah bahwa setiap individu bertindak untuk memaksimalkan kepentingannya sendiri (utilitas) (Irfan, 2002). Dalam konteks perusahaan, pemilik atau pemegang saham bertindak sebagai prinsipal, sedangkan manajer memiliki kedudukan sebagai agen. Dalam hubungan keagenan, timbul masalah antara pihak-pihak yang terlibat.

Masalah keagenan muncul karena manajer dan pemegang saham seringkali tidak mendapatkan informasi yang sama tentang perusahaan, meskipun harus diasumsikan bahwa manajer memiliki tujuan yang sama dengan pemiliknya (Keown et al., 2000 dalam Handoko, 2002). Masalah yang timbul dari hubungan keagenan ini sebenarnya bermula dari keinginan agen untuk tidak bertindak demi kepentingan terbaik prinsipal. Agen dapat membuat keputusan yang memaksimalkan kekayaannya lebih dari kekayaan prinsipal. Agen sebagai pihak yang memiliki informasi mengenai kondisi perusahaan saat ini dan yang akan datang tidak akan memberikan seluruh informasi yang dimilikinya kepada prinsipal karena berbagai alasan seperti kendala biaya penyajian informasi, waktu penyajian laporan, dan keinginan untuk menghindari risiko menunjukkan kelemahan.

Di sisi lain, prinsipal membutuhkan semua informasi yang relevan tentang kondisi perusahaan secara keseluruhan, tetapi tidak memiliki akses ke informasi internal perusahaan, meskipun informasi ini sangat berguna untuk pengambilan keputusan ekonomi. Hal ini membuat informasi menjadi asimetris. Asimetri informasi sangat berpengaruh dalam dunia akuntansi. Kekuatan informasi tidak terlepas dari kemampuannya untuk mempengaruhi tidak hanya keputusan individu, tetapi juga operasi pasar seperti pasar saham dan pasar tenaga kerja manajerial (Scott \& O'Brien, 2003).

Akuntabilitas sangat penting bagi kemampuan prinsipal dan pemangku kepentingan lainnya untuk menerima informasi yang akurat dan tepat waktu tentang informasi potensial yang mungkin memerlukan pengungkapan oleh perusahaan. Pandangan ini mewakili ruang lingkup pengungkapan perusahaan. Hal ini terkait erat dengan mekanisme yang mengurangi asimetri informasi dan mengurangi konflik kepentingan yang disebabkan oleh pemisahan kepemilikan dan kendali. Banyak studi empiris memberikan bukti bahwa pengungkapan secara signifikan terkait dengan asimetri informasi dalam hal kemampuannya untuk mengurangi asimetri informasi.

Pengungkapan merupakan suatu cara untuk mengurangi asimetri informasi, sebagaimana dinyatakan (Healy \& Palepu, 1993), bahwa proses pelaporan keuangan dapat menjadi mekanisme yang membantu manajer berkomunikasi dengan investor namun ternyata hal ini tidak efektif. Ketidaksempurnaan proses disebabkan oleh keunggulan informasi yang dimiliki oleh administrator, yang dapat menyebabkan terjadinya asimetri informasi. Banyak penelitian empiris telah dilakukan dalam kaitannya dengan pengungkapan laporan keuangan, apakah konsisten atau tidak. Diamond dan Venecchia (1991) dalam (KHOMSIYAH \& SUSANTI, 2003) menyatakan bahwa pengungkapan laporan keuangan mengurangi asimetri informasi. Hal ini juga didukung oleh penelitian Greenstein dan Sami (1994) dalam (Mardiyah, 2002). (Healy \& Palepu, 1993) dalam studi mereka menyatakan bahwa pengungkapan harus menjadi salah satu cara untuk mengurangi asimetri informasi dan bahwa proses pelaporan keuangan harus menjadi mekanisme yang berguna bagi manajer untuk berkomunikasi dengan investor. Hal ini didukung oleh hasil penelitiannya (Lev, 1988), yang menjelaskan bahwa pengukuran likuiditas pasar yang dapat 
diamati digunakan untuk mengidentifikasi tingkat asimetri dalam perdagangan dengan pelaku pasar modal. Lev mengatakan pengungkapan penuh harus mengurangi penipuan investor, karena asimetri informasi dikurangi melalui akses yang sama ke informasi. Hal ini menunjukkan bahwa masih banyak perdebatan mengenai temuan pengungkapan laporan keuangan. Oleh karena itu, penelitian ini menyajikan pengungkapan sukarela di lingkungan perusahaan untuk mengurangi faktor asimetri informasi dan pemantauan non-pengungkapan dan insentif agen yang perlu dipertimbangkan untuk meminimalkan asimetri informasi. Ini menawarkan banyak peluang untuk penyelidikan lebih lanjut, termasuk faktor-faktornya.

\section{2) METODE PENELITIAN}

Desain penelitian ini adalah studi kepustakaan dengan mengkaji atau menggali secara kritis pengetahuan, gagasan, atau wawasan yang terkandung dalam kepustakaan yang berorientasi keilmiahan dan merumuskan kontribusi teoritis dan metodologis pada topik tertentu. adalah. Metode analisis yang digunakan berupa analisis deskriptif, yaitu uraian yang teratur dari data yang diperoleh, yang dipahami dan dijelaskan untuk dipahami oleh pembaca.

\section{3) HASIL DAN PEMBAHASAN}

Teori agensi berkaitan dengan hubungan agen utama yang ada dalam pemisahan kepemilikan dan manajemen, atau dalam pemisahan risiko, pengambilan keputusan dan manajemen (Fama \& Jensen, 2008; Meckling, W. H., \& Jensen, 1976). Hubungan agen utama didefinisikan oleh Jensen dan Meckling (1976, hlm. 308) sebagai:

kontrak di mana satu atau lebih person (kepala sekolah) melibatkan orang lain (agen) untuk melakukan beberapa layanan atas nama mereka yang melibatkan mendelegasikan beberapa otoritas pengambilan keputusan kepada agen.

Hubungan agen utama yang paling umum dianggap adalah antara pemegang saham (sebagai kepala sekolah) dan manajemen (sebagai agen) suatu organisasi. Hubungan agen utama umum lainnya termasuk kreditor-pemegang saham (atau manajemen) dan hubungan manajemen-karyawan.

Menurut Deegan dan Samkin (2009, hlm. 71), teori agensi didasarkan pada asumsi sentral ekonomi bahwa ".. Semua tindakan individu didorong oleh kepentingan diri sendiri dan bahwa individu akan bertindak secara oportunistik untuk meningkatkan kekayaan mereka. Ada dua asumsi derivatif untuk teori agensi yang mengacu pada asumsi sentral, baik prinsipal maupun agen adalah maximizer utilitas yang cenderung memaksimalkan pengembalian mereka dengan segala cara dan kepentingan kedua belah pihak mungkin tidak selaras (Berle \& Means, 2017; Meckling, W. H., \& Jensen, 1976)

Kedua asumsi menunjukkan bahwa baik prinsipal dan agen memiliki kepentingan mereka sendiri dan mereka berusaha untuk memaksimalkan utilitas masing-masing, yang kemungkinan akan mengakibatkan konflik di antara mereka (yang disebut masalah agensi). Masalah agensi tidak dapat dihindari kecuali kedua belah pihak memiliki kepentingan yang sama sepenuhnya.

Asimetri informasi adalah konsep kunci lain dari teori agensi. Ini muncul ketika satu pihak 
dalam pengaturan agensi tertentu (atau hubungan) memiliki keunggulan informasi (yang disebut informasi pribadi) atas pihak lain. Asimetri informasi diasumsikan ada di sebagian besar pengaturan bisnis di mana manajer (agen) memiliki keunggulan informasi atas pemilik (kepala sekolah) karena manajer cenderung lebih terlibat langsung dalam sehari-hari. operasional perusahaan. Asimetri informasi dianggap memperburuk masalah agensi (Subramaniam, 2006).

Menurut teori agensi, masalah agensi muncul ketika kepala sekolah dan agen berusaha memaksimalkan kepentingan mereka sendiri, yang tidak selaras. Asimetri informasi adalah salah satu faktor kunci yang menyebabkan masalah agensi. Di sisi lain, modal intelektual dianggap sebagai pendorong utama bagi organisasi dalam ekonomi berbasis pengetahuan saat ini. Oleh karena itu, informasi sehubungan dengan IC (Intellectual capital) sangat dituntut oleh pemegang saham (atau investor) untuk pengambilan keputusan. Namun karena sebagian besar informasi tidak wajib diwajibkan oleh standar dan aturan akuntansi, itu terutama diungkapkan secara sukarela.

Adapun hubungan antara teori agensi dan pengungkapan IC, berpendapat bahwa disklosure sukarela IC dapat mengurangi asimetri informasi antara prinsipal dan agen (atau pemegang saham dan manajemen dalam pengaturan bisnis), dan sebagai konsekuensinya menghilangkan masalah dan biaya agensi terkait. Lebih khusus lagi, (Li, 2008) menyatakan bahwa pengungkapan IC sukarela dapat mengurangi perilaku oportunistik (misalnya insider trading) karena menyediakan paket pemantauan yang lebih intensif untuk perusahaan sementara (Singh \& Mitchell Van der Zahn, 2008) berpendapat bahwa pengungkapan IC voluntary dapat menurunkan biaya modal karena meningkatkan kepercayaan investor atau kreditor sehubungan dengan dampak IC pada penciptaan nilai perusahaan.

Asimetri informasi adalah bawahan perusahaan (manajer atau kepala operasi) yang memiliki lebih banyak informasi pribadi atau memiliki informasi rahasia tentang bidang pekerjaan dan fungsi tanggung jawab mereka daripada eksekutif di perusahaan induk, Diasumsikan menggunakan informasi pribadi mereka untuk membuat keputusan demi kepentingan diri mereka sendiri. Manajemen yang baik, tata kelola perusahaan, audit, pencegahan penipuan, dan insentif manfaat diadopsi untuk memecahkan masalah perilaku oportunistik, penipuan, dan korupsi yang mungkin terjadi dalam organisasi. Oleh karena itu, biaya agen untuk audit dan pencegahan penipuan tidak dapat dihindari. Selain itu, ada berbagai insentif biaya untuk mendorong eksekutif atau agen di anak perusahaan untuk mencoba dan bekerja mengikuti perusahaan induk dengan manfaat dan keuntungan keseluruhan organisasi adalah terutama. Tinjauan literatur sebelumnya oleh Chong dan Eggleton (2007) menemukan bahwa interaksi antara asimetri informasi dan komitmen organisasi secara positif mempengaruhi kinerja manajerial. Mereka menunjukkan bahwa asimetri informasi memiliki dampak langsung dan negatif pada kinerja manajerial. Chong and Law (2016) menunjukkan bahwa ketergantungan pada skema compensation insentif berbasis anggaran yang tinggi mengarah pada kepercayaan yang lebih tinggi pada pengawas, yang pada gilirannya menghasilkan komitmen organisasi yang lebih tinggi dan meningkatkan kinerja pekerjaan bawahan di bawah situasi asimetri informasi tinggi dalam suatu organisasi. Partisipasi adalah prinsip utama untuk pembangunan berkelanjutan dan manajemen risiko (Hedelin, Evers, Alkan-Olsson, \& Jonsson, 2017). Pendekatan kolaboratif meningkatkan kepercayaan dalam penggunaan informasi untuk pengambilan keputusan dan 


\section{TRANSEKONOMIKA: AKUNTANSI, BISNIS DAN KEUANGAN VOLUME 2 ISSUE 1 (2022)}

pemecahan masalah kelompok (Ulibarri, 2018;^ Kimmich, Gallagher, Kopainsky, Dubois, Sovann, Buth \&brethaut, 2019). Manajemen partisipatif penting bagi administrasi, juga mengurangi korupsi dan asimetri informasi keuangan (Thanathep, 2018).

Asimetri informasi keuangan didefinisikan sebagai bawahan perusahaan (manajer atau kepala operasi) memiliki lebih banyak informasi pribadi atau memiliki informasi rahasia tentang area tugas dan fungsi tanggung jawab mereka daripada manajer puncak mereka di perusahaan induk. Selain itu, informasi pribadi berisi informasi segmen, informasi manajemen internal, dan informasi pribadi (Chong \& Law, 2016; LATA, 2020; Ndofor et al., 2015). Secara rinci, informasi segmen adalah kepemilikan information tentang anggaran, keuangan, akuntansi , aset, kewajiban, laba rugi, pengeluaran di anak perusahaan, baik untuk pengungkapan seperti yang dipersyaratkan oleh standar dan untuk manajemen internal, dll. Informasi manajemen internal mengacu pada akuisisi dan akses ke informasi mengenai manajemen sumber daya manusia, pengambilan keputusan tentang staf baru, promosi staf, dan merekrut pemasok, penyedia layanan, kontraktor and, dll.

Terakhir, informasi pribadi adalah informasi pribadi dari pengetahuan unik individu yang disebabkan oleh intuisi, pengalaman, keyakinan, pembelajaran, atau kreativitas yang mendalam dalam pekerjaan. Pengetahuan muncul melalui pengamatan, pelatihan, dan dialog. Pengetahuan ini sulit untuk dibagikan tetapi dapat ditransfer untuk mendapatkan keuntungan administratif bagi organisasi. Bawahan memiliki lebih banyak informasi pribadi tentang lingkungan tugas mereka daripada atasan mereka, mungkin mereka dapat menggunakan informasi pribadi ini untuk membuat keputusan demi kepentingan diri mereka sendiri. Adanya informasi yang lebih pribadi merupakan ilustrasi asimetri informasi antara bawahan di anak perusahaan dan manajer puncak dalam holding firma. Akibatnya, dikatakan bahwa asimetri informasi tinggi, perilaku disfungsional lebih mungkin terjadi ketika asimetri informasi rendah didasarkan pada teori agensi. Di sisi lain, asumsi positif dalam teori agensi percaya bahwa bawahan memiliki lebih banyak informasi pribadi tentang pekerjaan mereka yang bertanggung jawab, sebagai hasilnya, akan memberikan informasi tambahan dan berguna bagi perusahaan informasi tambahan dan berguna untuk tujuan pengambilan keputusan dari manajer puncak di masa depan. Oleh karena itu, induk perusahaan hanya harus memotivasi bawahan untuk bekerja mengikuti kebijakan induk perusahaan untuk mencegah korupsi dalam organisasi. (Nel et al., 2018) menunjukkan bahwa asimetri informasi bermanifestasi ketika pihak one memiliki lebih banyak informasi daripada yang lain.

Perusahaan harus membuat laporan wajib tentang situasi ekonomi dan keuangan mereka. Untuk tujuan ini, perusahaan harus menyiapkan dan mengungkapkan laporan keuangan, yang merupakan saluran informasi utama tentang situasi perusahaan kepada pengguna eksternal. Dengan cara this, informasi menjadi tersedia untuk pengguna eksternal, yang akan menggunakannya untuk tujuan pengambilan keputusan ekonomi.

Informasi yang diberikan dalam laporan keuangan harus dilengkapi dengan pengungkapan yang tepat sehingga dapat dimengerti dan tidak mengarah pada salah tafsir. Pengungkapan ini bertujuan untuk memberikan informasi yang dianggap penting dalam mencapai tujuan pelaporan keuangan dan untuk melayani berbagai pihak yang memiliki kepentingan berbeda (Suwardjono, 2011). Pengungkapan memiliki dua karakteristik; pengungkapan wajib dan pengungkapan sukarela (Suwardjono, 2011). Pengungkapan sukarela adalah pilihan non-wajib bagi manajemen untuk memberikan akuntansi dan 
informasi lain yang dianggap relevan dan dapat mendukung proses pengambilan keputusan yang dilakukan oleh pengguna laporan keuangan, sedangkan pengungkapannya wajib jika diperlukan oleh konvensi / standar yang berlaku.

Tingkat kualitas akuntansi terkait dengan tingkat kelengkapan dalam pengungkapan laporan keuangan (Imhoff di (Agustiningsih et al., 2017)). Tingkat pengungkapan wajib dalam laporan keuangan pemerintah Indonesia masih rendah hal ini tercermin dari tingkat pengungkapan di mana tidak ada pemerintah daerah yang melakukan pengungkapan penuh. Kualitas keputusan akan lebih tinggi jika informasi keuangan disajikan secara transparan dan memenuhi kebutuhan pengguna sesuai dengan kondisi ekonomi saat ini.

Menurut (Board, 1987), tujuan utama informasi keuangan adalah untuk digunakan bagi pengguna ketika mengambil keputusan. Informasi akuntansi yang diungkapkan oleh perusahaan digunakan oleh berbagai pengguna (investor, pemberi pinjaman, pemasok, pesaing, manajer, layanan sipil) meskipun, seperti yang dinyatakan oleh (Board, 1987) investor, termasuk pemberi pinjaman, adalah pengguna utama, yang membutuhkan informasi keuangan untuk mengambil keputusan investasi yang tepat, setelah mengevaluasi posisi ekonomi dan keuangan perusahaan dan risikonya. Oleh karena itu, investor mengambil keputusan investasi / disinvestasi mereka dengan mengevaluasi tidak hanya pengembalian yang terkait dengan proyek investasi yang ditentukan, tetapi juga risikonya. Menurut (Cea, 1992), tujuan dari informasi yang diungkapkan oleh perusahaan adalah untuk membantu penggunanya dalam proses pengambilan keputusan mereka, jika informasi tentang risiko adalah dimasukkan, informasi yang diungkapkan akan lebih dekat dengan model keputusan yang ditetapkan dalam teori keuangan.

Seperti yang ditunjukkan, literatur akuntansi telah menunjukkan perlunya melaporkan risiko. Namun, beberapa referensi berurusan dengan masalah bagaimana menggabungkan informasi tentang risiko dalam model pengungkapan saat ini. Selain itu, referensi ini terutama berfokus pada risiko financial. FASB (melalui FAS No. 133) dan IAS 39 menangani pelaporan risiko yang terkait dengan aset keuangan dalam laporan keuangan. SEC (melalui FFR No. 48) estab-lishes, untuk perusahaan yang terdaftar, pengungkapan wajib risiko market yang timbul dari perubahan bunga dan nilai tukar mata uang asing yang merugikan, dan harga saham dan komoditas. Informasi ini bertujuan untuk membantu investor meningkatkan pengetahuan mereka tentang situasi keuangan perusahaan, asetnya dan risikonya. Dalam nada yang sama, beberapa makalah telah menganalisis kegunaan informasi ini untuk investor, seperti oleh (Jorion, 2002; Linsmeier et al., 2002; Thornton \& Welker, 2000) yang menyatakan bahwa pengungkapan informasi tentang risiko pasar berguna dalam mengambil keputusan investasi karena mengurangi tingkat ketidakpastian investor.

Berdasarkan hal-hal tersebut diatas secara sederhana dapat dikatakan bahwa disclosur mempunyai hubungan dengan asimetri informasi, yakni disclosure dapat digunakan untuk mengatasi atau meminimalisasi asimetri informasi. Hal ini dapat dijelaskan sebagai berikut: Melalui publikasi laporan keuangan yang didalamnya termasuk disclosure, pasar dapat menilai sejauh mana perusahaan telah mengungkapkan semua informasi relevan. Jika semua informasi relevan telah di-disclose, berarti asimetri informasi seharusnya berkurang. Berkurangnya asimetri informasi dapat diketahui dari bid-ask spread. Sernakin kecil bid-ask spread yang tejadi mengindikasikan berkurangnya asimefi informasi. Menurunnya bid-ask spread juga mencerminkan respon positif pasar terhadap informasi yang terkandung dalam publikaai laporan keuangan, termasuk disclosurnya. 


\section{4) KESIMPULAN}

Melihat penjelasan dan penjelasan di atas, kita dapat melihat bahwa teori keagenan dapat menjelaskan bagaimana asimetri informasi terjadi. mengasumsikan adanya hubungan keagenan yang merupakan suatu kontrak, dimana pihak prinsipal yang terdiri dari satu atau lebih orang mengikat pejanjian dengan pihak agen untuk melaksanakan sejumlah jasa atas nama prinsipal yang mencakup pendelegasian sejumlah kekuasaan untuk membuat keputusan kepada pihak agen. Hubungan tersebut memberi konsekuensi bahwa manajemen yang telah diberi otorisasi untuk membuat keputusan sadar harus bertindak dalam situasi yang menguntungkan klien mereka. Namun, jika terjadi ketidakseimbangan dalam perolehan informasi, maka akan timbul masalah implementasi. Dalam hal ini, agen, salah satu pihak, memiliki lebih banyak informasi daripada yang dia miliki dan tidak mengungkapkan semua informasi yang dimiliki agen untuk keuntungan pribadi. Mengingat pentingnya informasi bagi prinsipal untuk pengambilan keputusan yang optimal, untuk mengatasi asimetri informasi tersebut maka perlu dilakukan pengungkapan pengungkapan laporan keuangan perusahaan. Hal ini telah dibuktikan secara empiris oleh sejumlah peneliti, yaitu pengungkapan dapat mengatasi atau meminimalkan simetri informasi. Keuntungan dan kerugian sebagai dampak yang dirasakan oleh perusahaan dalam mengungkapkan laporan keuangannya dapat dilihat dari beberapa indikator. Namun, tujuan utama pemenuhan kebutuhan pemangku kepentingan dapat tercapai.

\section{DAFTAR PUSTAKA}

Agustiningsih, S. W., Murni, S., \& Putri, G. A. (2017). Audit findings, local government characteristics, and local government financial statement disclosure. Review of Integrative Business and Economics Research, 6(3), 179.

Berle, A. A., \& Means, G. C. (2017). The Modern Corporation and Private Property. In Modern Economic Classics-Evaluations Through Time. https://doi.org/10.4324/9781315270548-16

Board, F. A. S. (1987). Statement of Financial Accounting Standards No. 95: Statement of Cash Flows. Financial Accounting Standards Board (FASB), Stamford. Acesso Em, 28.

Cea, J. L. (1992). In search of a better and more complete accounting information about the income risk. Comunicación al XV Congreso de La European Accounting Association. Madrid.

Chong, V. K., \& Law, M. B. C. (2016). The effect of a budget-based incentive compensation scheme on job performance. Journal of Accounting \& Organizational Change, 12(4). https://doi.org/10.1108/jaoc-02-2015-0024

Fama, E. F., \& Jensen, M. C. (2008). Agency Problems and Residual Claims', Journal of Law and Economics, XXVI (2), June, 327-49. International Library of Critical Writings In Economics, 214(3), 365.

Jorion, P. (2002). How informative are value-at-risk disclosures? The Accounting Review, 77(4), 911-931.

LATA, P. (2020). The influences of participatory management and corporate governance on the reduction of financial information asymmetry: Evidence from Thailand. The Journal of Asian Finance, Economics, and Business, 7(11), 853-866. 
Li, J. ( G. ). (2008). A Longitudinal Study of Corporate Social Disclosure in Chinese Listed Companies 'Annual Reports : 2002 to 2006. Disertasi, July.

Linsmeier, T. J., Thornton, D. B., Venkatachalam, M., \& Welker, M. (2002). The effect of mandated market risk disclosures on trading volume sensitivity to interest rate, exchange rate, and commodity price movements. Accounting Review, 77(2). https://doi.org/10.2308/accr.2002.77.2.343

Meckling, W. H., \& Jensen, M. C. (1976). Managerial behavior, agency costs and ownership structureMeckling, W. H., \& Jensen, M. C. (1976). Managerial behavior, agency costs and ownership structure. Journal of Financial Economics. https://doi.org/DOI: 10.1016/0304-405X(76)90026-X. Journal of Financial Economics.

Ndofor, H. A., Wesley, C., \& Priem, R. L. (2015). Providing CEOs With Opportunities to Cheat: The Effects of Complexity-Based Information Asymmetries on Financial Reporting Fraud. Journal of Management, 41(6). https://doi.org/10.1177/0149206312471395

Nel, G. F., Smit, E., \& Brummer, L. M. (2018). The link between internet investor relations and information asymmetry. South African Journal of Economic and Management Sciences, 21(1). https://doi.org/10.4102/sajems.v21i1.1966

Singh, I., \& Mitchell Van der Zahn, J. W. (2008). Determinants of intellectual capital disclosure in prospectuses of initial public offerings. Accounting and Business Research, 38(5), 409-431.

Subramaniam, N. (2006). Agency theory and Accounting research: An overview of some conceptual and empirical issues. In Methodological Issues in Accounting Research.

Suwardjono, S. (2011). Teori akuntansi perekayasaan pelaporan keuangan. Edisi Ketiga, Cetakan Kelima. Yogyakarta: BPFE Yogyakarta.

Thornton, D., \& Welker, M. (2000). Impact of mandated market risk disclosures on investorperceived exposure to commodity prices: The case of oil and gas producers. Queen's University, Kingston, Canada. 